\title{
Organizing Pneumonia Associated with Oxaliplatin-Combined Chemotherapy: A Case Report
}

\author{
Eun Joo Lee ${ }^{a}$ Sang Yeub Lee ${ }^{a}$ Kwang Ho In ${ }^{a}$ Chul Hwan Kim ${ }^{b}$ \\ Sanghoon Park ${ }^{\mathrm{c}}$ \\ ${ }^{a}$ Division of Respiratory and Critical Care Medicine, Department of Internal Medicine, ${ }^{b}$ Department of Pathology, \\ Korea University College of Medicine, and ' Department of Internal Medicine, KEPCO Medical Foundation, Hanil \\ General Hospital, Seoul, Republic of Korea
}

\section{Key Words}

Interstitial pneumonia - Organizing pneumonia •

Oxaliplatin · Pulmonary toxicity

\section{Abstract}

Objective: To report a case of oxaliplatin-combined chemotherapy-induced interstitial lung disease. Clinical Presentation and Intervention: A 57-year-old man was referred complaining of dyspnea and fever after treatment with an oxaliplatin-combined chemotherapeutic agent for metastatic colorectal cancer. Fever development and spontaneous subsidence were observed during the chemotherapeutic course repeatedly until the 9 th cycle. A computer-tomographic (CT) scan revealed bilateral, peripherally distributed, patchy consolidation suggestive of an interstitial lung disease. As a confirmative step, video-assisted thoracoscopic surgical biopsy was attempted; the characteristic intraluminal organizing fibrous plug in the bronchioles and alveoli was seen. Corticosteroid therapy was administered, which rapidly improved the patient's symptoms and chest CT findings. Conclusion: This case showed that oxaliplatin may be implicated in the etiology of interstitial lung disease, since withdrawal of the drug resulted in improvement of interstitial lung disease.

Copyright $\odot 2011$ S. Karger AG, Basel

\section{KARGER}

Fax +4161306 1234

E-Mail karger@karger.ch

www.karger.com (c) 2011 S. Karger AG, Basel

1011-7571/12/0211-0089\$38.00/0

Accessible online at:

www.karger.com/mpp

\section{Introduction}

The combination of oxaliplatin with leucovorin and 5 -fluorouracil (FOLFOX regimen) has recently been accepted as first-line chemotherapy for advanced or metastatic colorectal cancer, and its use has been shown to significantly improve survival [1]. Common adverse events of oxaliplatin are hematological and gastrointestinal tract toxicities, and neurolopathy [2]. Recently we observed a rare case of oxaliplatin-induced interstitial lung disease, specifically organizing pneumonia.

\section{Case Report}

A 57-year-old man was referred to our department complaining of dyspnea and fever. Three years previously, he had undergone surgical treatment with low anterior resection for a colonic adenocarcinoma with surgical stage T3N2M0 and had received adjuvant chemotherapy with oral tegafur/uracil.

During the follow-up, several metastatic pulmonary nodules appeared on a chest computer-tomographic (CT) scan, and the serum carcinoembryonic antigen level was elevated. The chemotherapy regimen was therefore changed to 5 -fluorouracil, leucovorin and oxaliplatin (FOLFOX). This chemotherapy was a bimonthly regimen with intravenous oxaliplatin $\left(85 \mathrm{mg} / \mathrm{m}^{2}\right)$ ad- 
Fig. 1. Chest CT scan revealed bilateral, peripherally distributed, patchy consolidation (arrows).
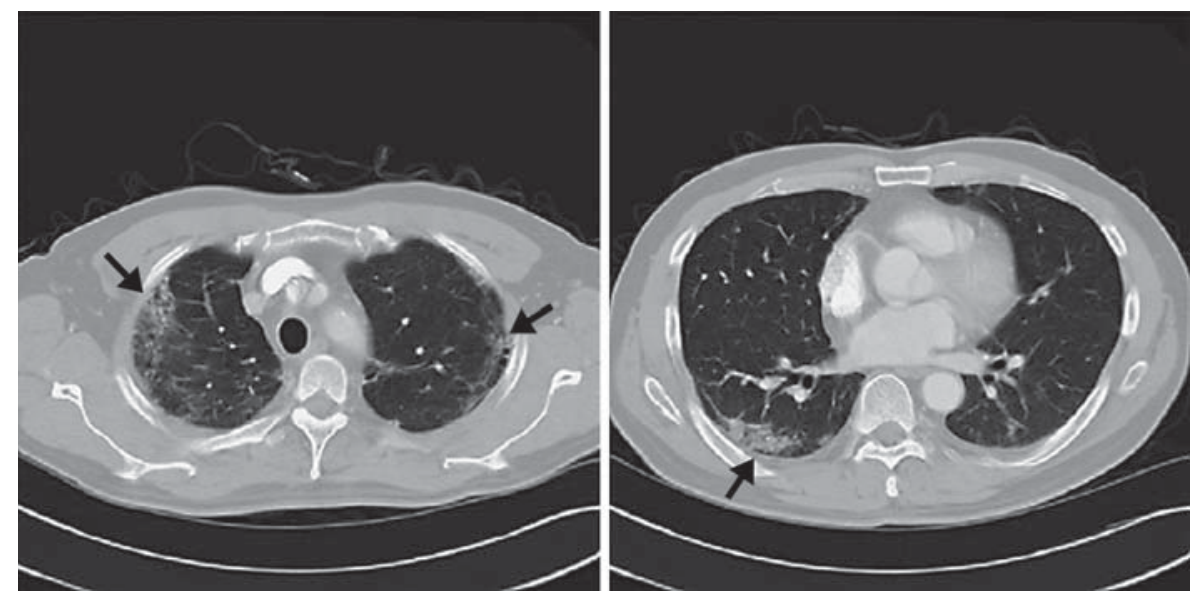

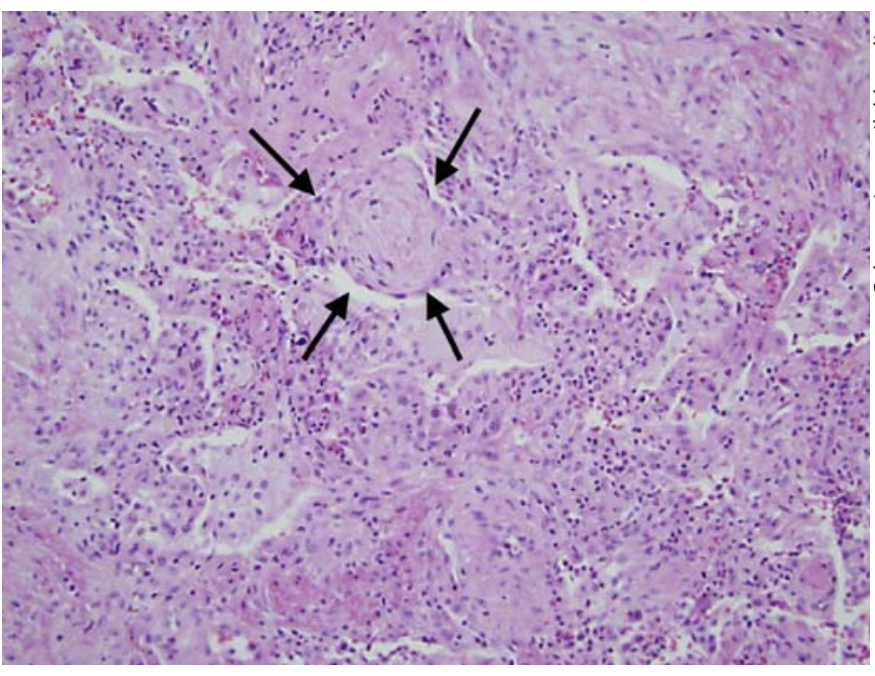

Fig. 2. Video-assisted thoracoscopic surgical biopsy showed an intraluminal organizing fibrous plug (arrows) in the alveoli, consistent with an organizing pneumonia pattern. HE. $\times 400$.

ministered on day 1 , leucovorin $\left(200 \mathrm{mg} / \mathrm{m}^{2}\right)$ added on days 1 and 2 , and 5 -fluorouracil $\left(400 \mathrm{mg} / \mathrm{m}^{2}\right.$ as a bolus and $600 \mathrm{mg} / \mathrm{m}^{2}$ in continuous infusion for $22 \mathrm{~h}$ ) added on days 1 and 2 . No complications were noticed during the first 3 cycles of FOLFOX chemotherapy. However, the fourth cycle of oxaliplatin infusion was interrupted because of fever $\left(38.7^{\circ} \mathrm{C}\right)$. Fever surveillance studies including chest radiography, sputum culture, urine culture and blood culture were not remarkable. Laboratory tests revealed a white cell count of $4,610 / \mathrm{mm}^{3}$, a hemoglobin concentration of $11.6 \mathrm{~g} / \mathrm{dl}$, a platelet count of $166,000 / \mathrm{mm}^{3}$ and an erythrocyte sedimentation rate of $67 \mathrm{~mm} / \mathrm{h}$. After the fever had spontaneously subsided, chemotherapy was continued with the remaining leucovorin and 5-fluorouracil. However, this episode (i.e. interruption of chemotherapy by a febrile period after infusing oxaliplatin and continuance after fever subsidence) occurred repeatedly until the 9th cycle of chemotherapy. Just prior to the 9th cycle, a follow- up chest CT scan was made, and it revealed bilateral, peripherally distributed, patchy consolidation (fig. 1), suggesting interstitial lung disease. As a further evaluation, bronchoalveolar lavage was performed using a fiberoptic bronchoscope also for a microbiological study. The bronchoalveolar lavage study revealed no infectious cause, with a total cell count of 36 cells/ $\mu$ l with $28 \%$ neutrophils, $64 \%$ lymphocytes and $1 \%$ eosinophils, also ruling out an eosinophilic pneumonia. A video-assisted thoracoscopic surgical biopsy was taken, and the histological finding showed a characteristic intraluminal organizing fibrous plug in the bronchioles and alveoli (fig. 2). With a presumptive diagnosis of oxaliplatininduced organizing pneumonia, he was treated with prednisolone ( $1 \mathrm{mg} / \mathrm{kg} /$ day), and FOLFOX chemotherapy was discontinued. His symptoms and radiological abnormalities accordingly improved (fig. 3).

\section{Discussion}

This was a case of oxaliplatin-induced interstitial drug disease that was finally diagnosed by video-assisted thoracoscopic surgical biopsy. Generally, a drug-induced interstitial lung disease can be established by a definite temporal association between exposure to a specific drug and the development of respiratory symptoms and signs, and by compatible laboratory findings, such as radiology, bronchoalveolar lavage or a pathological pattern. However, drug-induced interstitial lung disease is rare, comprising fewer than $5 \%$ of all cases. It is an important etiology because withdrawal of the culprit drug frequently results in improvement of the condition [3], as happened with our patient. The exact mechanism of oxaliplatin-induced interstitial lung disease is not clearly understood, but the direct toxic effect of the drug, rather than an immunology-driven mechanism, has been suggested based on a negativity to lymphocyte stimulation testing [4]. 
Fig. 3. After steroid treatment, chest CT scan showed nearly complete resolution (arrows) of the consolidation.
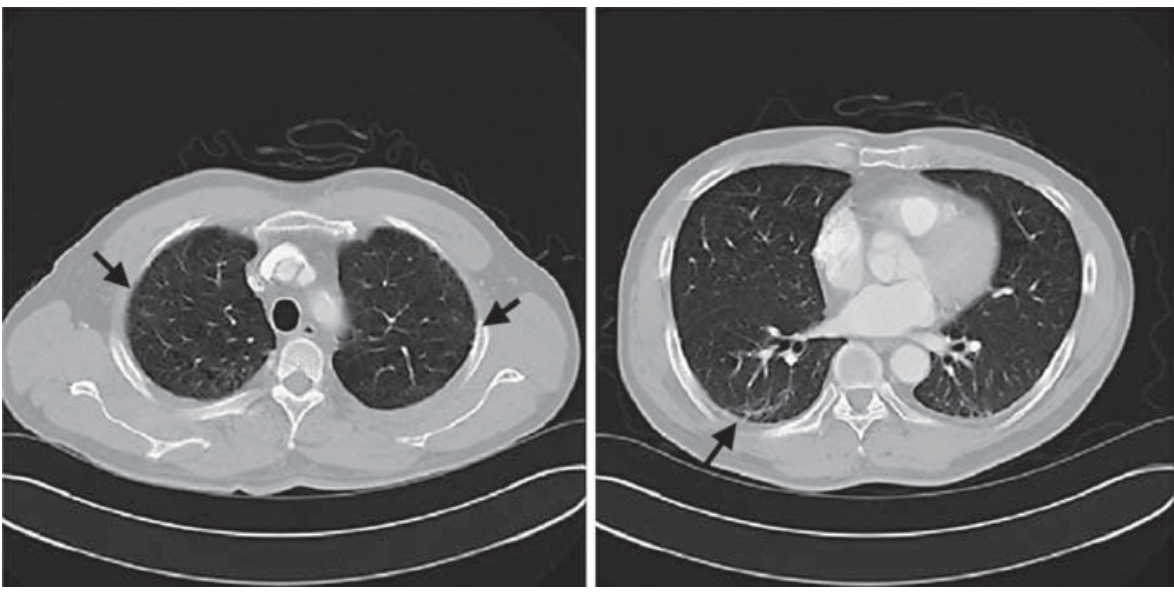

Table 1. Reported cases of oxaliplatin-induced interstitial lung diseases

\begin{tabular}{|c|c|c|c|c|c|c|c|c|}
\hline $\begin{array}{l}\text { Ref. } \\
\text { No. }\end{array}$ & $\begin{array}{l}\text { Age, } \\
\text { sex }\end{array}$ & $\begin{array}{l}\text { Symp- } \\
\text { toms }\end{array}$ & $\begin{array}{l}\text { Final } \\
\text { cycles }\end{array}$ & Radiology & Pathology or BAL & Diagnosis & Treatment & Prognosis \\
\hline $\begin{array}{l}\text { Present } \\
\text { case }\end{array}$ & $57, \mathrm{M}$ & $\mathrm{D}, \mathrm{F}$ & 9 & $\begin{array}{l}\text { bilateral, patchy } \\
\text { consolidation }\end{array}$ & $\begin{array}{l}\text { VATS Bx: organizing } \\
\text { pneumonia }\end{array}$ & $\begin{array}{l}\text { organizing } \\
\text { pneumonia }\end{array}$ & $\begin{array}{l}\text { stop the } \\
\text { drug, steroid }\end{array}$ & $\begin{array}{l}\text { nearly complete } \\
\text { resolution }\end{array}$ \\
\hline 4 & $60, \mathrm{M}$ & $\mathrm{D}$ & 7 & $\begin{array}{l}\text { GGO, consolidation in } \\
\text { lower lobes }\end{array}$ & $\begin{array}{l}\text { TBB: organizing diffuse } \\
\text { alveolar damage pattern }\end{array}$ & acute lung injury & prednisone & complete remission \\
\hline 5 & $60, \mathrm{~F}$ & C, D & 8 & $\begin{array}{l}\text { patchy bilateral nodular } \\
\text { infiltrates in lower lobes }\end{array}$ & BAL: eosinophilia of $29 \%$ & $\begin{array}{l}\text { eosinophilic pneu- } \\
\text { monia associated } \\
\text { with oxaliplatin }\end{array}$ & $\begin{array}{l}\text { stop the } \\
\text { drug }\end{array}$ & progressive resolution \\
\hline 6 & $74, \mathrm{M}$ & C, D, F & 6 & $\begin{array}{l}\text { linear and nodular } \\
\text { densities which were } \\
\text { becoming confluent }\end{array}$ & $\begin{array}{l}\text { TBB: did not show an } \\
\text { infective process }\end{array}$ & & $\begin{array}{l}\text { methyl- } \\
\text { prednisolone }\end{array}$ & death \\
\hline 7 & $64, \mathrm{M}$ & $\mathrm{D}$ & 2 & $\begin{array}{l}\text { reticular opacity and a } \\
\text { honeycomb change in } \\
\text { lower lobes }\end{array}$ & $\begin{array}{l}\text { TBB: organizing } \\
\text { pneumonia }\end{array}$ & $\begin{array}{l}\text { pulmonary } \\
\text { fibrosis }\end{array}$ & steroid & improvement \\
\hline 7 & $75, \mathrm{M}$ & $\mathrm{D}$ & 1 & $\begin{array}{l}\text { diffuse GGO and } \\
\text { consolidation with } \\
\text { interlobular thickening }\end{array}$ & $\begin{array}{l}\text { TBB: diffuse alveolar } \\
\text { damage with hyaline } \\
\text { membrane formation }\end{array}$ & AIP & steroid & improvement \\
\hline 8 & $66, M$ & $\mathrm{D}$ & 12 & $\begin{array}{l}\text { patchy bilateral } \\
\text { consolidation in lower } \\
\text { lobes }\end{array}$ & $\begin{array}{l}\text { autopsy: diffuse alveolar } \\
\text { damage with fibrous } \\
\text { organization }\end{array}$ & $\begin{array}{l}\text { pulmonary } \\
\text { fibrosis }\end{array}$ & steroid & death \\
\hline 9 & $30, \mathrm{~F}$ & C, D & 6 & bilateral alveolar infiltrates & $\begin{array}{l}\text { VATS Bx: organizing } \\
\text { pneumonia }\end{array}$ & $\mathrm{COP}$ & prednisone & complete resolution \\
\hline 10 & $71, \mathrm{M}$ & C, D, F & 6 & $\begin{array}{l}\text { extensive fibrotic infiltrates } \\
\text { and new GGO }\end{array}$ & none & $\begin{array}{l}\text { hypersensitivity } \\
\text { reaction }\end{array}$ & $\begin{array}{l}\text { antibiotics, } \\
\text { steroid }\end{array}$ & death \\
\hline 10 & $77, \mathrm{~F}$ & C, D & 12 & $\begin{array}{l}\text { subpleural honeycombing } \\
\text { and traction bronchiectasis }\end{array}$ & none & UIP & no therapy & $\begin{array}{l}\text { gradual improvement of } \\
\text { symptoms and stable } \\
\text { findings on radiographs }\end{array}$ \\
\hline 10 & $69, M$ & $\mathrm{H}$ & 6 & $\begin{array}{l}\text { bilateral honeycombing } \\
\text { and traction bronchiectasis }\end{array}$ & $\begin{array}{l}\text { TBB: a small focus of } \\
\text { organizing pneumonia }\end{array}$ & UIP & $\begin{array}{l}\text { N-acetyl- } \\
\text { cysteine }\end{array}$ & improvement \\
\hline
\end{tabular}

$\mathrm{M}=$ Male; $\mathrm{F}$ = female $\mathrm{D}=$ dyspnea $\mathrm{C}=$ cough $\mathrm{F}$ = fever $\mathrm{H}=$ hypoxemia $\mathrm{GGO}=$ ground glass opacity $\mathrm{BAL}=$ bronchoalveolar lavage; $\mathrm{TBB}=$ trans bronchial lung biopsy; VATS Bx = video-assisted thoracoscopic surgical biopsy; AIP = acute interstitial pneumonia; COP = cryptogenic organizing pneumonia; UIP = usual interstitial pneumonia. 
Recently, a number of cases of oxaliplatin-induced interstitial lung disease were reported (table 1) [4-10]. Presumptive diagnoses varied, e.g. acute lung injury (acute interstitial pneumonia, hypersensitivity reaction), eosinophilic pneumonia, usual interstitial pneumonia or organizing pneumonia. The interval from chemotherapy infusion to the development of interstitial pneumonia also varied from less than 10 days to more than 6 months. The most common symptom was dyspnea; others were cough and fever, as in our case. Male gender was predominant. The principal treatment for oxaliplatin-induced interstitial lung disease was steroids, while a few patients were treated with antibiotics or $\mathrm{N}$-acetylcysteine or no treatment. Most cases responded fairly well to appropriate treatment, but 3 out of 10 were fatal despite steroid treatment. Notably, most of these reports lacked a surgical lung biopsy, except for 2 cases of diffuse alveolar damage [8] and organizing pneumonia [9]. The case involving organizing pneumonia was a 30-year-old woman who complained of cough, which differs clinically from our case of an elderly man with fever.
Most previous reports failed to explain whether the lung disease was caused exclusively by oxaliplatin or by any other combined chemotherapeutic agent. In particular, one report of a cryptogenic organizing pneumonitis [9] may well have been corrected to organizing pneumonia instead. Our case was unquestionably caused by oxaliplatin rather than an unknown etiology.

\section{Conclusion}

This case showed that oxaliplatin is implicated in the etiology of interstitial lung disease and withdrawal may be well worth considering, as evidenced by the improvement in the condition of our patient after withdrawal of the drug.

\section{Acknowledgement}

This study was supported by a Korea University grant.

\section{References}

1 Wolpin BM, Mayer RJ: Systemic treatment of colorectal cancer. Gastroenterology 2008; 134:1296-1310.

-2 Cassidy J, Misset JL: Oxaliplatin-related side effects: characteristics and management. Semin Oncol 2002;29:11-20.

3 Camus P, Fanton A, Bonniaud P, Camus C, Foucher P: Interstitial lung disease induced by drugs and radiation. Respiration 2004;71: 301-326.

-4 Trisolini R, Lazzari Agli L, Tassinari D, Rondelli D, Cancellieri A, Patelli M, Falcone F, Poletti V: Acute lung injury associated with 5-fluorouracil and oxaliplatinum combined chemotherapy. Eur Respir J 2001;18:243245 .
Gagnadoux F, Roiron C, Carrie E, MonnierCholley L, Lebeau B: Eosinophilic lung disease under chemotherapy with oxaliplatin for colorectal cancer. Am J Clin Oncol 2002; 25:388-390.

6 Pasetto LM, Monfardini S: Is acute dyspnea related to oxaliplatin administration? World J Gastroenterol 2006;12:5907-5908.

-7 Jung KH, Kil SY, Choi IK, Seo JH, Shin C, Kim YS, Kim JH: Interstitial lung diseases in patients treated with oxaliplatin, 5-fluorouracil and leucovorin (FOLFOX). Int J Tuberc Lung Dis 2006;10:1181-1182.
8 Mundt P, Mochmann HC, Ebhardt H, Zeitz M, Duchmann R, Pauschinger M: Pulmonary fibrosis after chemotherapy with oxaliplatin and 5-fluorouracil for colorectal cancer. Oncology 2007;73:270-272.

9 Garrido M, O’Brien A, Gonzalez S, Clavero JM, Orellana E: Cryptogenic organizing pneumonitis during oxaliplatin chemotherapy for colorectal cancer: case report. Chest 2007;132:1997-1999.

10 Wilcox BE, Ryu JH, Kalra S: Exacerbation of pre-existing interstitial lung disease after oxaliplatin therapy: a report of three cases. Respir Med 2008;102:273-279. 